\title{
City Branding: Tourism Marketing Strategy City of Padang
}

\author{
Fitri Adona \\ STMT Trisakti \\ Jakarta, Indonesia \\ luthe.mafrudoh@gmail.com
}

\author{
Lut Mafrudoh \\ Politeknik Padang West Sumatera \\ Padang, Indonesia
}

\begin{abstract}
A city considered to have qualified a strong brand if it has a history, the quality of the place, lifestyle, culture,and diversity of the marketable as a tourist and investment destination. Kota Padang is considered to have almost all of these qualifications, but a way of marketing their regions considered less effective and less understood by investors. The main constraint is the selection of non-conforming products and ways of communicating that does not refer to the branding communication and city branding. This study aims to look at the tourism marketing strategy in Padang through any city branding and inhibiting factors and supporting the efforts of the implementation of city branding. The research method applied is qualitative method. The method is likely to use a descriptive analysis. This study further highlight the process and meaning (the perspective of the subject). The theoretical basis used as a guide in order to stay focused and research in accordance with the facts on the ground. Focus Group Discussion (FGD) is used as a method of data collection. The results of this study, city branding is not applied in accordance with the process of work, more spontaneity without planning. As a result, vision, mission, and purpose of government is not consistent with the brand they were offering. Most bureaucrats Sumbar have not been able to explain their understanding of the consequences and city branding. On the other hand, the participation of the community to promote the city branding they are not so visible.
\end{abstract}

Keywords-tourism marketing, branding, branding communication, city branding, branding strategy

\section{INTRODUCTION}

Marketing a city, province, and the country is very dynamic, competitive, and important today. The market leaders are trying to stand out than their competitors. Business cities, provinces, and countries trying to portray himself as best as possible by applying the right brand strategy that provides many benefits and advantages. Location, geography, product, and personal figure of an area used as a reference to create a brand to communicate the identity of its location. As a result, cities, provinces, and countries actively campaigned through advertising, direct mail, and other communication devices.

Padang City, West Sumatra Province, Indonesia has almost all the qualifications a strong brand, but a way of marketing their regions considered less effective and less understood by investors. The main constraint is the value of selected products to be marketed and how to communicate it does not refer to the branding communication. The city is also not organized tourism campaign. Pemasaraan area was carried out by the city of Padang for regional autonomy law provides an opportunity for the government to develop the region of Padang.

Potential areas like a product or service that is packaged and given brand (branding) that have characteristics that can distinguish it from other areas of potential. In the last two decades, the city of Padang has spawned several branding: "Padang Kota Bengkuang," "Padang Democracy city", "Padang City of Industry Brains," "Padang City of Commerce," "Padang Old Twon," and "Your Padang Motherland" , In addition to "Your Padang Motherland" all city branding proficiency level is not a part of the tourism marketing strategy, but only as an identifier that area alone and form civic pride of the city.

Purpose of this study was to review the communication strategies and marketing of tourism industry of Padang, West Sumatra, Indonesia through the city branding in order to assist the region in defining and communicating city branding well and suggest a marketing campaign that is able to communicate the variety of the city's potential to the market and investors.

In relation to the issue, the problem in this research is:

a. How does tourism marketing strategy in Padang through city branding?

b. What are the factors inhibiting and supporting the implementation of city branding effort in Padang?

Tourism marketing is a process of planning and execution, starting from the conception, pricing, promotion, until the distribution of goods, ideas and services, to conduct exchanges that satisfy individual and its institutions "(American Marketing Association (AMA) in Rhenald Kasali (1998: 53). In general, marketing management can be defined as an art and a science to be able to choose the target market, and acquire, retain, and grow customers through the creation, delivery and communication of superior value to the customer "(Kolter and Keller 2009: 62).

On the other hand, Schultz and Barnes interpret branding communication as internal and external communications among others through sales promotion, events, public relations, direct marketing (sending catalogs, mail, telephone, fax, or email), corporate sponsorship 'product or service with in collaboration with other companies as sponsors', and advertising 'introduced products or services through a wide range of advertising' (1999). 
Based on these definitions, city branding can be defined as a process of forming brand city or a region to be recognized by the target market (investors, tourist, talent, event by using icons, slogans, exhibitions, as well as the positioning is good in various forms of media promotion. A city branding is not just a slogan or promotional campaign, but an overview of thoughts, feelings, associations and expectations that come from a person's mind when a person is seeing or hearing a name, logo, product service, event, or a variety of symbols and designs are described.

Meanwhile, destination branding understood as an attempt to change perceptions about a place or destination to see the difference an other place to be chosen as a destination. Morgan and Pritchard (2004) suggested five stages to destination branding in changing the image of an area: (1) the market investigation, analysis and strategic Recommendations (at the early stages of the formation of branding a city of this, marketers areas conduct research and mapping of the potential market, everything which can be developed, and drafting strategies); (2) brand identity development (in this stage brand identity was formed based on the vision, mission, and the image to be formed by the locality) (3) brand launch and introduction: communicating the vision (after tagline introduced the brand that is introduced with the involvement of the whole components through media relations, such as advertising, direct marketing, personal selling, websites,

brochures, or event organizer, the film markers, destination marketing organizations (DMOS) and journalist) (4) brand implementation (include processes that elaborate compilation of the budget for support a variety of marketing communications program in delivering the brand message; budgeting is an important aspect of doing a branding) (5) monitoring, evaluation, and review (monitoring done on programs being implemented to detect irregularities, deficiencies, etc., the results were evaluated for improvement).

Schultz and Barnes defines branding as a management strategy of a brand whose activities regulate all elements that aim to establish a brand (1999: 43). Gelder defines branding strategy as a what was supposed to be achieved by a brand in relation to consumer attitudes and behavior. In implementing its strategy, branding strategy Gelder divide as: brand positioning, brand identity and brand personality (2005: 29-41).

Brand positioning is a way of demonstrating superiority of a brand and its distinction from competitors. In making the branding of the city, it takes an understanding of what people think about the target market the city as well as ensure the placement of the most positive positioning in the perception of the audience towards the city compared to competitors.

Brand identity is a collection of aspects of the delivery of the brand, from the background, principles, goals, and ambitions for the brand. Through branding identity, consumers can perceive the product in question. Components branding identity includes the name, logo, colors, jingle, packaging design, slogan, endorser brands, and character. The components of brand identity is intended to strengthen the brand of a city.

Brand personality is a way to increase the attractiveness of the brand in the eyes of consumers. Brand given certain characteristics that can be obtained through the communication process and the experience of the person who introduced the brand itself.

\section{METHOD}

This study used a qualitative approach. The focus of research undertaken are:

Firstly, tourism marketing strategy through city branding in the city of Padang, which includes the determination of elements.

a. Brand personality of Padang with elements: Ritual (associated with certain events), symbol (the image is considered to have value added), Heritage of Good (the specific advantages), The aloof Snob (City brand shows the character of rating), The Belonging (City Brand made travelers feel part of a large group), Legend (history);

b. Brand positioning of Padang with elements: Determine the positioning: City Brand

c. Padang Kota brand identifiers with elements coffee and spice: Positioning (Feature, Benefit, target audience, positioning statement); Verbal (Brand / Brand Name), Descriptor / Product Description, Nomenclature / Glossary, Positioning Tagline; Visual (Logo, Packaging, Media advertising), Experiential (Identity experience, Technology support, third party)

Secondly, inhibiting factors and support in implementing the city of Padang city branding include:

a. Supporting factors,

b. Obstacle factor

The research location is in the city of Padang. Pre-test of the "Campaign Marketing Communications West Sumatra Branding Through Communication" was conducted by using Focus Group Discussion (FGD). FGD called interview group also belonging to the kind of focused or structured interviews. FGD according Hoed, 1995: 1 in Harahap (2012: 60) was designed with the aim of exposing the group's perceptions about a problem. Researchers took members of FGD based on criteria agreed that the community leaders (Penghulu / traditional leaders, Ulema / religious leaders and Cadiak Clever / the scholars, bundo Kanduang / woman diuakan and respected), bureaucrats and practitioners, all of which amounted to 7 people. Discussions FGD eat a maximum of 2 hours. The steps required are discussions, data collection, data reduction, data presentation, and conclusion.

\section{RESULT}

Although it is not for the purpose of tourism marketing, in the history of the city of Padang has sparked some branding. Branding "Padang Bengkuang City," appeared only because of the concern for the preservation of fruit that tastes sweet and contains a lot of water. This fruit represents the topography of Padang is hot because it is located on the seaside. The fruit is widely cultivated and become a typical product of this city, but from time to time yam farms on the wane since the development of the city and for farmers, the selling price was not promising.

Branding "Padang Democracy City", raised the pride of the people of Padang Minangkabau society as others have a tradition of consensus agreement that contains the values of democracy. Branding "Padang City of Industry Brains," arose 
because of the pride of Padang who once had many educated leaders and implement educational system surau by scholars, and has coal and cement started to do through Teluk Bayur. Branding "Padang Old City," raised as a concern would suburb of Sungai Batang Arau, Mudik Market, Market Tower and the temple that was almost extinct by the earthquake of 2009. This area was once the economic center and the Dutch government at the time of the VOC. South Padang region has old buildings of the past glory beraksitektur rest of Europe was founded in the 19th century and early 20th century.

Unlike the previous branding, "Padang Your Motherland" raised in 2014 as part of a tourism marketing strategy. Branding is selected with the hope to summarize what is aspired in the previous branding. "Your Padang Motherland" is raised because the people of Padang has a unique cultures in organizing community life. As Minang people, most of the people of Padang still adopts matrilineal kinship system or by the maternal line. The system is considered unique and only found in five parts of the world in the country of China, Indian, India, Ghana, and the United States that needs to be preserved.

Until 2016, city branding "Your Padang Motherland" underwent various developments. People familiar with the various city Padang City brand and subbrand. The city of Padang subbrand for all city brand is as follows: culinary subbrand ( "Rendang Padang", "Soto Padang", "Nasi Padang", "Sate Padang", "Gulai Kapalo Lauak"); subbrand geographic ( "Padang Beach", "Mount Padang", "Bridge Siti Nurbaya", "Nirwana Beach", "Air Manis Beach); subbrand customs and cultural values (Padang "Matrilieal City", "Padang Kota Perantau", "Silek Pauah / Silat Pauh"); subbrand slogan ( "Tambuah Ciek / Add More", "Lamak Bana / Delicious", "Rancak Bana / Good Right", "Balado / Full Chilli Hot and Spicy", "Onde Mande"); subbrand legend ( "Malin Kundang", "Siti Nurbaya"); subbrand lifestyle ( "Padang Kota Pemburu ", "Padang Convention City").

On the other side, the indicators in the tourism sector in the city of Padang is not only on the number of tourists but also the placement of Padang as a major tourist destination. Diversification of tourism products and tourism marketing strategy right will be key to success in achieving the vision of Padang as a tourist destination. Through a growing city branding in the community, the city of Padang is expected to successfully increase the number of tourist arrivals in the period 2004-2019. With a new target that you want to make Padang as a major tourist destination, the process of the establishment of city branding should really be done properly through three (3)stages: brand personality, brand positioning, and brand identifiers.

\section{A. Brand Personality of Padang}

Brand personality of Padang meet 6 elements: the rituals, symbols, heritage of good (the specific advantages), the aloof snob (city brand shows the character of rating), the belonging (sense of tourists) and legends. The sixth of these elements does not create city brand of Padang getting stronger, because the slogan of city brand "Padang Your Motherland" understood only by a limited circle, not for most residents of Padang. Selection of the word "mother" is assessed as forced and is linked to the notion of "maternal lineage" or "matrilineal" carried city branding. It is almost identical in fact with the slogan of Padang before: "Padang Kota Tercinta" or "Padang Kota Tercinta, kujaga dan Kubela" totally incompatible with the desire to promote cooperation sector expects investors.

Padang city actually also has no problem with the aloof snoob elements and the belonging that is expected to strengthen the brand city of Padang Padang because historically the largest trading port in Sumatra that involves many nations and leave a legacy of the old town as evidence of the diverse history of the nation. It becomes a potential Padang visited by diverse tribes.

\section{B. Brand Positioning of Padang}

Brand positioning of Padang promoted as a meeting place throughout the Minang culture in line with the brand personality owned by the city of Padang. Determination of Padang brand positioning based on unieqly element (uniqueness) and excess travel products offered thus forming positioning as a city of Padang as the central meeting Minang culture.

In communicating the brand positioning are bebarapa elements: be creative, simplicity, own, dominate and protect, and use Reviews their language. The fourth element is very precise in communicating the brand positioning, but still weak in the element be creative. The local government is still using ways that are very formal and limited in communicating the brand positioning.

Other elements of the simplicity, own-dominate-protect and use Reviews their own language is very precise due to the orientation to be achieved is the global tourism market so there needs to be an adjustment to the international language of English, Mandarin, and Arabic in tourism marketing Padang.

\section{Identifiers Brand Kota Padang}

Brand identifier can be classified into three groups, namely the elements of the brand itself (name, logo, symbols, characters, slogans, jingles, mark / signature, a spokesman for the brand / spokesperson), products (services and all marketing activities and marketing program support), and other associations whose meaning associated with the brand (a person, a place, or an event / specific experience).

Brand identifiers of Padang with element positioning, verbal, visual, experiential has not been able to distinguish the products offered in the city of Padang. Elements of verbal, visual created brand personality is capable of representing the city of Padang to understand the character of the city verbally and visually, but the experiential element is still weak due to the lack of bids in Padang travel products so that tourists visit in the city of Padang is still in a relatively short deadline. Deadline tourist visits dominant under 24 hours, even if there are older, they are immigrants who had returned home.

On the other side, the target market is a very important part of the marketing strategy menuyusun. Although the target market is the focus always discourse is European, Asian, and Arabic, there is no any document that confirms it. The target market is still unclear and unfocused. Estimates of the 
Netherlands, Australia, Malaysia, and Singapore as the target market is more due reference to the statistical reports that describe the highest level of tourist arrivals per year. Arab inserted into the discourse of the target market for the province of West Sumatra is now promoting halal tourism. Arab travelers characters always ask for evidence in the form of halal certification outentik of each service they will receive.

\section{Obstacles and Supporting Implementing City Branding In the city of Padang}

\section{1) Supporting factors}

Factors supporting the city of Padang city branding process is the commitment of mayors and local government officials in building the city of Padang in accordance with the potential and the character of the town that had been included in the Medium Term Development Plan (RPJMD) Padang City from 2014 to 2019. Tourism is one of the six main points that form the basis, focus and main goal of development can be achieved in a period of 5 years. Marine tourism by utilizing Padang Beach lovely and clean and the adjacent islands is the potential of Padang is very important in addition to trade.

RPJMD also did not specify the nature of tourism activities that have close links with other sectors, agriculture, industry, trade and services enable the development of tourism sector in an integrated manner with other relevant sectors so that the city's economic growth becomes faster and efisien.Meskipun Thus, factors more important is the public awareness of Padang drive the economy and preserving the culture of Minang be an asset for the city of Padang. Infrastructure development also helped supporting factors are important because of the tourists visiting the city of Padang should be supported by a variety of means, the infrastructure is good too.

\section{2) Obstacle factor}

Budget constraints in the tourism sector of Padang is the limiting factor in the process of city branding. It does not only lead to a lack of development of tourism products offered to tourists, but also in disseminating this concept, both in the bureaucracy and in the community. Weak coordination antarsatuan local work on city branding resulted in infrastructure is not strong city branding. A result of information, tourism products ditaawarkan was not clear and has not been able to strengthen the city brand.

Positioning 'act local managers in designing products and marketing mix in order to create a certain impression in the memory of consumers so that consumers understand and appreciate the Minang culture' has not been able to make a common perception antarstakeholder in developing various tourism programs. Inconsistency on the ground rubbing invitation positioning are carried, feared obscure brand city of Padang.

\section{CONCLUSION}

In the last two decades, the city of Padang has spawned several branding: "Padang Bengkuang City," "Padang Democracy City", "Padang City of Industry Brains," "Padang City of Commerce," "Padang Old City," and "Padang Your Motherland" , In addition to " Padang Your Motherland" all city branding proficiency level is not a part of the tourism marketing strategy, but only as an identifier that area alone and form civic pride of the city. The study also found some subbranding which includes culinary ("Rendang Padang," "Soto Padang," "Sate Padang," "Nasi Padang"); geographic ( "Padang Beach," "Mount Padang", "Bridge Siti Nurbaya"); legend ( "Malin Kundang", "Siti Nurbaya"); the term ( "Tambuah Ciek / Add More", "Lamak Bana / Delicious"; "Rancak Bana / Good Right"); attitude to life ( "Padang Kota Perantau", "Padang Matrilineal City", "Padang Democracy City").

From the fifteenth subbrand if associated with a brand city of Padang "Padang Your Motherland set by the government, then there exists a subbrand very supportive and are not directly related. Subbrand very supportive are: "Padang" "Mount Padang", "Bridge Siti Nurbaya", Malin Kundang "," Siti Nurbaya "," Padang Kota Perantau "," Padang Matrilineal City"and" Padang Democracy City "is a sub -branding that amplifies the content as well as the Minang culture is the focus of the brand city of Padang. At least variables that strengthen Minang culture that has been entered in the subbranding among others: "matrilineal" and "Democracy". However, in general, the fifteenth subbranding it indirectly supports the city brand "Your Padang Motherland" because the fifteenth variables are reflected in subbrand it can be said there are in the region and other countries.

Subbranding in the process of branding though not entirely rooted in city branding "Padang Your Motherland", meaning it will not be ambiguous and undermine the concept of city brands that have launched or create the perception that it is not clear for travelers in understanding the character of the city of Padang if the slogans are replaced or more socialized and explained.

\section{REFERENCE}

Aaker, David A. (2004). Manajemen Ekuitas Merek.

Al Ries dan Jack Trout. (2001). Positioning:Marketing Mark Plus \& Co. Bandung: Mizan Pustaka.

Alexander, Morissan. (2010). Periklanan Komunikasi Pemasaran Terpadu. Jakarta: Ramdina Prakarsa.

Anholt. S. (2007). Competitive Identity - The New Brand Management for Nations, Cities, and Regions, Palgrave Macmillan, New York.

Anik, Rahmasari. (2005). Pemasaran Pariwisata. Bandung: PT. Rafika Aditama.

Branding Kota Semarang Dengan Kota di Indonesia (Solo \& Surabaya) dan Kota Dunia (Kota Amsterdam). Eprints.undip.ac.id, tanggal akses 27 Mei 2012.

Fadalah, Ali Akbar dan Nia Kurniasih Pontoh. ---. "Penerapan City Branding di Indonesia: Studi Kasus Kota Pekalongan, JawaTengah" dalam Jurnal Perencanaan Wilayah dan Kota A SAPPK V1N2 (534-543).

Fandeli .C. (1995). Dasar-Dasar Manajemen Kepariwisataan Alam. Yogyakarta: Penerbit Liberty. Gelder, Sicco van. 2005. Global Brand Strategy:Unlocking Branding Potential Across. Countries, Cultures \& Markets. Jakarta: PT Gramedia Pustaka Utama.

Harahap, M. Y. (1996). Tinjauan Merek Secara Umum dan Hukum Merek di Indonesia Berdasarkan Undang- 
Undang No. 19 Tahun 1992. Bandung: PT Citra Aditya Bakti.

Hari A. K. (1997). Kepariwisataan. Jakarta, Grasindo. Jakarta: Mitra Utama.

Kaertajaya. H. (2002). Creating Effective Marketing Plan. Jakarta: PT. Gramedia Pustaka Utama.

Kasali, R. (1998). Membidik Pasar Indonesia. Jakarta: PT. Gramedia Pustaka Utama.

Kotler, P., H., DH \& Rein, IJ. ()1993. Marketing

Kotler. P. (2005). Manajamen Pemasaran. Jakarta, PT. Indeks. Kelompok Gramedia.

Morgan, N., Pritchard, A., \& Pride, R. (2004). Destination Branding-Creating The Unique Destination Proposition. (2ndEd). Oxford: Butterworth.

Muchamad, Bani Noor. (2015). Konsep Ekspresi Kota Sebagai Pendekatan Membangun Atau Memperkuat Citra Kota).

Muktiali, Mohammad. (2012). "Kaji Banding City.

Philip .K. \& Kevin .L. K. (2009). Manajemen Pemasaran. Jakarta: Erlangga.

Places: Attracting Investment, Industry and Tourism to Citis, States and Nations.

Schultz. D. E., \& Barnes. B. E. (1999). Strategic Br and Communication Campaigns. Lincolnwood, IL:NTC Business Books. 